\title{
Mapping Improvement of Community Empowerment in the village of Development
}

\author{
Author \\ Sukaris, Budiyono Pristyadi, Alkusani \\ Correspondence \\ Universitas Muhammadiyah Gresik \\ Sukaris21@umg.ac.id
}

\begin{abstract}
:
Community empowerment is Carried out in order to reduce poverty and unemployment, the which in turn will lead to an increase of in community welfare. However, the data-based empowerment programs have not been done much. So we need the first step in the success of community empowerment, it must start with understanding the community and its dynamics. The understanding needed is an understanding of the social and institutional arrangements of the community and an assessment is needed to design a good community development programs, and in accordance with the needs of the community so that the program can Achieve the right targets. The purpose of this coding program is to analyze the characteristics, potentials and problems of the village, analyze alternative empowerment programs for the targeted village communities and analyze and implement alternative programs for community empowerment activities. The approach used in resolving Reviews These services priority is the social mapping survey methods and the participatory rural appraisal (PRA) method, with the target of being Sambipondok Village communities and Manyar Sidorukun Village. The results show that both villages have dimension index in the lagging characteristics and developing indexes. The potentials of the two villages are Generally different, such as the potential for tourism villages and Also the potential for. with the target of being Sambipondok Village communities and Manyar Sidorukun Village. The results show that both villages have dimension index in the lagging characteristics and developing indexes. The potentials of the two villages are Generally different, such as the potential for tourism villages and Also the potential for. with the target of being Sambipondok Village communities and Manyar Sidorukun Village. The results show that both villages have dimension index in the lagging characteristics and developing indexes. The potentials of the two villages are Generally different, such as the potential for tourism villages and Also the potential for.
\end{abstract}

Keywords: empowerment, social mapping, the index left behind, developing the index.

Received: 05 Agustus 2019. Accepted: 21 Agustus 2019

\section{Introduction}

In August 2017, the BPS revealed that the number of unemployed rose to 7:04 million, from the previous 7:03 million Increase in August 2016. This was accompanied by a Decrease in the Open Unemployment Rate or TPT, from 5.61\% to 5:50\%. TPT itself is a percentage of the number of unemployed people included in the working age population of the total workforce. This year, precisely in February 2018, BPS reported that the number of unemployed in Indonesia Decreased by 140,000. The percentage of TPT Also dropped from 5:33 to 5:13\%\% in February 2017. The total number of labor force in 2018 Increased by 2:39 million from February 2017 to 133.94 million people, with unemployment of 6.87 million and Reviews those who work 127.07 million. (https://glints.com).
Data shows the number of unemployed people in East Java in February 2018 Reached 809.45 thousand people, with the Open Unemployment Rate (TPT) are tending to decline, where the TTP in February 2017 by 4:00 fell to 3.85 percent in February 2018. In February 2018, TPT for unemployed with education level Vocational High School occupies the highest position at 9:08 percent, Followed by TPT Diploma I / II / III education at 7:09 percent, unemployed with University education at 5.85 percent. Unemployed people with the cancel TPT are at elementary school level and below, amounting to 1.77 percent and unemployed with junior high school education of 3:48 percent. When Compared to the situation in February 2017, TPT in almost most levels of 
education experienced a decline except for unemployed people with secondary vocational and university levels (http://bappeda.jatimprov.go.id).

Based on the data BPS, the amount of FDI - Domestic investment realization in Gresik Regency since 2014 was 18.73 trillion and in 2015 it was 9012 trillion. The Open Unemployment (TPT) in Gresik level but instead should have the TPT Decreased Increased from 5:06 in 2014 to 5.67 in 2015. (https://duta.co). The Although the data shows that the number of industries Increased in Gresik Regency, the number of unemployment did not Decrease but instead Increased. This could happen Because The increase is in the industry was not accompanied by an Increase in employment. The industry uses more technology in its operations the which absorbs only a small workforce. Based on Reviews These conditions, it is time for the people of Gresik Regency to be encouraged to develop entrepreneurship programs as a way to empower existing communities. And it will Also Be Able to encourage poverty reduction in Gresik Regency.

Susenas Based on the data, the level of poverty in Gresik Regency percentage is still higher than the poverty level in East Java and National. And when Compared to the MDG targets, it is still very far from Achieving the targets. This means that Gresik Regency is still a burden for East Java and National Provinces, even though in terms of Regency Minimum Wages (UMK), Gresik Regency is classified as having the second highest MSE level in East Java province, the which is $\mathrm{Rp} \mathrm{3,580,370.64}$ below Surabaya City UMK the which is equal to Rp. 3,583,312.61 (listed https://news.detik.com/beritajawa-timur/d-3735259/umk-2018-digedok-ini-dUMK-38-area-in-jatim; rois jajeli, November 21, 2017 ).

Based on the above conditions, in order to reduce the level of open unemployment and reduce the level of poverty in Gresik Regency, it is time to Make Efforts to Increase community empowerment. As a first step in the success of community empowerment, it must start with understanding the community and its dynamics. The understanding needed is an understanding of the social and institutional arrangements of the community and the need for assessment to design a good community development programs, and in accordance with the needs of the community so that the program can Achieve the right targets.
Social mapping the which in general is an attempt to describe the socio-economic and cultural conditions of the community, one of the areas being the locations of studies is in Sambipondok village and Manyar Sidorukun village. The villages are villages in urban areas where many companies stand with various businesses, both extractive in nature, processing or fabrication. A correct understanding of the potential and condition of resources around the community living (physical and human resources), the social structure and institutions of the community, the problems and potentials of conflict and social change are a necessity for later on to be Able to empower According to village communities Reviews their needs appropriately, Activities to Obtain this information can be Carried out through a social mapping activity. With the next Social Mapping Activity Mapping, an empowerment activity Appropriate models will be developed later. (Sukaris, 2019).

This is in line with Law No. 6 of 2014 concerning Villages or the Village Law is an instrument of law to Achieve the welfare of the community and the independence of the Village. The village has a significant role in how to Determine the direction of the vision to be Achieved. An important aspect in the process of Achieving this vision is the empowerment of rural communities. In terms of village community empowerment, an important instrument that needs to be known is how the actual problems experienced by the village and how big or strong the village potential is. Through this instrument the village can Recognize by digging up information, the extent of the problems experienced in relation to village development and the potential it has to push the village out of the trap of the problem.

The purpose of this coding program is to analyze the characteristics, potentials and problems of the village, analyze alternative empowerment programs for the targeted village communities and analyze and implement alternative programs for community empowerment activities.

\section{Method \\ - Model of Community Service Activities}


Gresik Regency UMK is the second highest in East Java

Industrialization is growing rapidly in Gresik Regency Gresik location as a buffer Surabaya

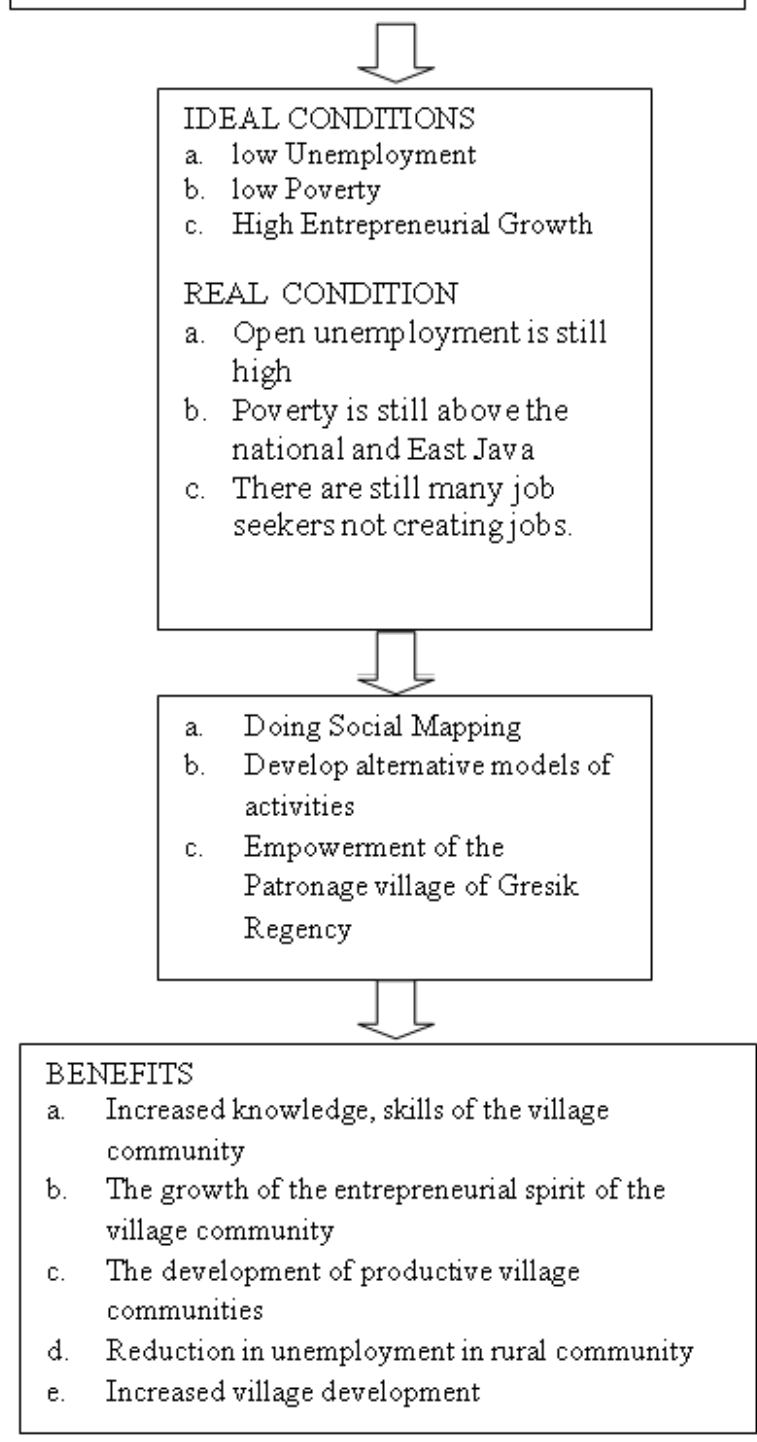

\section{- Priority prolems}

Sambipondok Village, and Manyar Sidorukun Village are villages in the northern area of Gresik Regency, where Reviews These villages are surrounded by many industries the which should be quite promising in helping to reduce unemployment in the region. But in fact, Reviews These villages are still high in unemployment and the slow pace of village development is occurring

\section{- Problem Solving Approach}

The approach used in solving problems Reviews These priority is the social mapping survey methods and the participatory rural appraisal (PRA) method. PRA is a technique for developing and developing operational programs in village level development. This approach is taken by Mobilizing local human and natural resources and local institutions to
Accelerate productivity improvement, increase of community income and be Able to Increase the empowerment of local communities. This method is used to identify problems experienced by rural communities.

\section{- Activity Plans}

The planned activities that will be Carried out are:

a. Disseminating questionnaire interviews to explore potentials village.

b. Undertake to explore the demographic, Socioeconomic and cultural characteristics of rural communities.

c. Conduct interviews and observations to explore village problems.

d. Conduct a small workshop to formulate the required models of village community empowerment activities.

\section{- Partner Participation}

Implementation of community service programs targeting the target villages by involving village communities, village leaders, youth groups, PKK and village Officials

\section{- Target and Output}

Social Mapping Results, the which include:

a. The structure and dynamics of society and their associated attributes

b. Identification of the potential of the village, social and community institutions.

c. Identification of community strategic problems, social-ecological, socio-economic and community institutions,

d. Alternative community empowerment programs needed

\section{Results and Discussion}

\section{- Sambipondok Village}

The discussion of Sambipondok village is Described as follows:

\section{Profile of Sambipondok Village}

The village sambipondok profile Described below is taken from the https://id.wikipedia.org/wiki/Sambi_Pondok, Sidayu,_Gresik page, Described as follows:

Sambi The cottage is one of the villages in Sidayu sub-district, Gresik Regency, East Java province, Indonesia. This village is located in the west of Golokan village and east of Bolo.100\% people in this village are Muslim and have one mosque, the Al Hidayah mosque. the main product in this village is the Kripik 
uyel food. This village IS ALSO Sidayu the smallest village in the sub-district. The history of Sambipondok Village is Inseparable from the history of the Gresik Regency Community. This village was originally called Sambipondok Village with a village head for life, but With the Changing Times and the Act of the Village, the Position of the Village Head is Limited to Periods. The village heads who have served up to now are as follows: Kasbun (1935 to 1955), Miyadi (1956 to 1968), Adjri Noto (1969 to 1990), H. Adjri Noto (1990 to 2000), Drs. Sumadi (2000 to 2008), and Drs. Sumadi (2008 to 2013), Mashuda SE (2013 to 2019).

The total population of Sambipondok village in 2015 has now Reached 717 people with the following details: Male: 348 Soul: Soul 369 Number of KK: $166 \mathrm{KK}$ This village is practically a Muslim. Sambipondok Village is one of the villages located in Sidayu subdistrict, Gresik Regency. Geographically Sambipondok Village is located at $7^{\circ} 21^{\prime}-7^{\circ}$ 31 'South Latitude and $110^{\circ} 10^{\prime}-111^{\circ} 40^{\prime}$ East Longitude. The topography of this village is in the form of medium land the which is around 12 $\mathrm{m}$ above sea level. Based on the data in Gresik district CPM in 2008, during 2008 the rainfall in Sambipondok Village averaged 22C-30C. The most rainfall occurred in December to reach $35 \mathrm{C}-40 \mathrm{C}$ the which is the highest rainfall during the period 2008-2010. Regional Boundary, North: Bolo Village, Ujung Pangkah, South: Kertosono Village, Sidayu, East: Golokan Village, Sidayu, West: Wadeng Village, Sidayu. Distance: Distance to District: $7 \mathrm{Km}$, Distance to Regency: $31 \mathrm{Km}$, Distance to City Province: $47 \mathrm{Km}$. Area: The area of Sambipondok village is 54 ha, with the following details: Settlement: 4 ha, Rice fields: 20 ha, Plantation and cleaning fields: Divided into 30 ha Number of RTs: 5 Number of RWs: 2. $45 \%$ of the village area is rice fields and plantations that are still beautiful.

\section{Achievement of Sambipondok Village Development Index}

The index of achievements are presented in Table 1 below:

Table 1: Sambipondok Village development index
Table 1: Sambipondok Village development index

\begin{tabular}{|c|c|}
\hline Indicator & IPD \\
\hline $\begin{array}{l}\text { Availability and access to Kindergarten/RA (Islamic Kindergarten)/ } \\
\text { BA }\end{array}$ & 2.2785 \\
\hline Availability and access Elemantary School & 1.1552 \\
\hline Availability and access Junior High School & 1.9247 \\
\hline Availability and access Senior High School & 1.9044 \\
\hline Availability andEasy Access to Hospital & 1.0865 \\
\hline Availability and Easy Access to Maternity Home & 1.5486 \\
\hline Availability and Easy access to PHC & 1.8628 \\
\hline Availability and Easy access to Polyclonc/ Treatment Hall & 2.4717 \\
\hline Availability and Easy access to Doctor's Office & 1.3034 \\
\hline Availability and Easy access to Midwife Practice & 2.3947 \\
\hline Availability and Easy access to Poskesdes / Polindes & 2.0169 \\
\hline Availability and Easy Access to Pharmacy & 1.5214 \\
\hline Availability of Shops, Minimarket and Grocery & 1.9617 \\
\hline Availability of Market & 0.0000 \\
\hline Availability of Restaurant and Food Stalls & 1.2171 \\
\hline Availability of hotel or lodging accomodation & 0.0000 \\
\hline Availability of Bank & 0.0000 \\
\hline Electrification & 1.4042 \\
\hline Lighting condition of main road & 1.6828 \\
\hline cooking Fuel & 1.7778 \\
\hline Source for Drinking Water & 2.9948 \\
\hline Water source for bathing/ Washing & 2.4110 \\
\hline defecation Facility & 1.3713 \\
\hline Availability and quality of celullar Communications & 1.2832 \\
\hline Availibility of Internet Facility and psotal or good delivery Facilities & 0.3459 \\
\hline Traffic and Road Quality & 1.7427 \\
\hline Road Accountability & 1.4985 \\
\hline The availabilty of Public Transportation & 4.2658 \\
\hline Public Transportation Operation & 3.3808 \\
\hline Tarvel time per kilometer of Transportation to the sub-distric office & 1.7713 \\
\hline Cost Per kilomenters transportation to Sub District office & 2.8017 \\
\hline $\begin{array}{l}\text { Travel time per kilometer of transportation to the Regent / mayor's } \\
\text { office }\end{array}$ & 1.1374 \\
\hline Cost per kilometer of transportation to the Regent / mayor's office & 0.0000 \\
\hline Handling extraordinary events (KLB) & 1.9512 \\
\hline Handling of malnutrition & 2.0934 \\
\hline Availability of sportsfacilities & 0.6700 \\
\hline The existence of sports activity groups & 0.7040 \\
\hline Village autonomy & 2.6018 \\
\hline Completeness of village government & 0.0000 \\
\hline Village assets/wealth & 1.1914 \\
\hline Quality of Human Resources for Village head & 1.8642 \\
\hline Quality of HR Village's Secertary & 2.7937 \\
\hline
\end{tabular}

From the Data Obtained indexes that still need attention are first; economic infrastructure consisting of availability of shops, availability of access to shops and pharmacies, shops, minimarkets, or grocery stores, markets, restaurants, Restaurants or food stalls, availability of hotel or lodging accommodations and availability of financial institutions. Second: communication and information infrastructure such as; cellular and ICT networks. And the third is the availability of sports facilities both from infrastructure and citizen involvement.

3. IPD Dimensions and Achievements in the Village Development Index

The achievements of the Sambipondok village development index can be summarized in Table 2 as follows: 
Table 2: Achievements of IPD dimensions

\begin{tabular}{|l|l|l|l|l|l|l|}
\hline Dimension & $\begin{array}{l}\text { Total } \\
\text { Indicator } \\
\text { value }\end{array}$ & $\begin{array}{l}\text { weights } \\
\text { Dimensions }\end{array}$ & $\begin{array}{l}\text { value } \\
\text { Dimensions }\end{array}$ & $\begin{array}{l}\text { TNI/ } \\
\text { BD }\end{array}$ & IPD & Information \\
\hline Basic services & 1.0734460 & 0.3261591 & 0.0994538 & 3.291173 & 65.82346 & flourish \\
\hline $\begin{array}{l}\text { Infrastructure } \\
\text { condition }\end{array}$ & 0.8224993 & 0.2525512 & 0.0632694 & 3.256723 & 65.13446 & flourish \\
\hline $\begin{array}{l}\text { Accessibility/ } \\
\text { Transport }\end{array}$ & 0.8299098 & 0.2097380 & 0.1037396 & 4.079412 & 81.46824 & Mandiri \\
\hline Public service & 0.2709234 & 0.1094455 & 0.0677909 & 2.475418 & 49.50837 & left behind \\
\hline $\begin{array}{l}\text { The } \\
\text { Governance }\end{array}$ & 0.4225536 & 0.1091940 & 0.0945107 & 2.475418 & 77.402111 & Mandiri \\
\hline
\end{tabular}

a. Village potential and PKK institutional involvement

Table 3: PKK potential and membership

\begin{tabular}{|c|l|l|}
\hline No. & \multicolumn{1}{|c|}{ potential Village } & \multicolumn{1}{c|}{ Information } \\
\hline 1 & name PKK & PKK Sambipondok \\
\hline 2 & Activities that have been carried out PKK & $\begin{array}{l}\text { Event 10 PKK program <-building activities and } \\
\text { skills }\end{array}$ \\
\hline 3 & Do own cooperative & Yes \\
\hline 4 & Does owning your own business & No, due to lack of skilled human resources \\
\hline 5 & The obstacles faced by the PKK today & Human resources are less skilled \\
\hline 6 & The potential of the PKK now & Skills about cooking \\
\hline
\end{tabular}

Based on the the data above, it can be explained that the potential of villages Relating to existing institutions, especially for mothers, have skills and excellence in culinary or cooking, so that all they have to do is develop in terms of human resources and prepare for its sustainability.

\section{b. Village potential and Youth institutional involvement}

Table 4: Youth institutional potential

\begin{tabular}{|l|l|l|}
\hline No. & potential Village & Information \\
\hline 1 & Name of youth & Putra Buana \\
\hline 2 & $\begin{array}{l}\text { Activities that have been } \\
\text { implemented }\end{array}$ & Development of ruralyouth \\
\hline 3 & Do own cooperative & No, because it has not been programmed \\
\hline 4 & Does owning your own business & $\begin{array}{l}\text { No, members of the youth prefer to seek employment } \\
\text { outside the village }\end{array}$ \\
\hline 5 & The obstacles faced by youth today & Lack of youth pemudiyang compact \\
\hline 6 & The potential of the youth today & Soccer field, volley ball court \\
\hline
\end{tabular}

In the case of youth institutions, institutions have already been formed but need to Strengthen capacity and synergize Reviews their resources and potential

\section{Alternative Models of Empowerment of Sambipondok Village Communities}

So that the alternative models for the empowerment of Sambikpondok Village is specifically for the PKK is the provision of culinary skills in supporting tourism villages items, namely culinary business, so that cooking training needs to be done, for example with cooking demonstrations, cooking is cooking training or how to make a food given to the PKK mothers. The purpose of cooking training activities is to hone the ability of mothers in the culinary field, innovate in making a food based on traditional local food and after participating in training mothers can practice cooking in their homes. As a forum for mothers to be Able to entrepreneurship through culinary.

Strengthening the capacity of youth institutions needs to be prepared to support the economic growth of villages specifically related to tourism villages. Based on preliminary observations showing that the empowerment of Karangtaruna as manager of tourism villages, villages Karangtaruna in managing tourism forms the awareness of tourism-aware Youths roomates are endorsed by the Decree of the Village Head. The young people who are members of the tourism awareness group are Also trying to promote the Waterboom tourism village, both through social media and media pamphlets, banners and other media with the aim that the tourist village is known by the public at large, roomates in can turn increase of the number of tourists visiting the village tour. In terms of independence in managing tourism villages, youth cadets in 2018 received training from Muhammadiyah University Gresik in the form of standard tourism village marketing strategies to promote tourism villages by strengthening promotion through social media, the which can increase of the number of tourists visiting the place, both local tourists to visit the tourist village. In the future strengthening the capacity of human resources in terms of services must be improved.

\section{Conclusion}

The achievement of community service activities by holding a social special mapping from the economic point of view that a). knowledge and understanding of of participants in understanding the potential of the village is quite good with the ability to map the weaknesses and strengths of Reviews their villages, $b$ ). of participants have been Able to identify economic businesses and the role of institutions in their villages, c). Participants have been Able to identify productive businesses based on local products, and $d$ ). the overalls of participants want a follow-up program from a Similar empowerment program. Considering the large benefits of community service activities, further training needs to be Carried out in accordance with the current social mapping, 
selecting one of the businesses that has the greatest potential for Reviews those who have the opportunity to be interested in the community at the moment and Potentially economically developed. Connect with village-owned enterprises, and there must be continuity and supervision of the program after Reviews These community service activities so that the sustainability of activities and community empowerment can have economic added value.

\section{References}

Java Bappeda, 2018. East Java Unemployment Rate 3.85 Percent (http://bappeda.jatimprov.go.id/2018/05/10/t ingkat-pengangguran-terbuka-jawa-timursebesar-385-persen/ ; BAPPEDA Java; May 10, 2018)

Duta.co, 2017. Tens of Thousands Unemployment in Gresik Still Far from Solution, (https://duta.co/puluhan-ribu-penganggurandi-gresik-masih-jauh-dari-solusi/; 28 April 2017; the ambassador. co).

Glints.com, 2018. Facts About Unemployment in Indonesia in 2018, (https://glints.com/id/lowongan/faktapengangguran-indonesia/; maria juwita, 17 July 2018)

id.wikipedia.org. Pondok Sambi, Sidayu, Gresik,https://id.wikipedia.org/wiki/Sambi_ Pondok, Sidayu, Gresik,

Sukaris, S. (2019). Social-Mapping Platform Planning For Sustainable Community Empowerment. Entrepreneurship Research Journal, 2 (1), 52-61. doi: 10.30587/ jre.v2i1.796. 